\title{
The Effectiveness of SQ3R Integrated with Digital Interactive Multimedia to Reading Skill at SMP PMT Prof. Dr. Hamka 2 Padang
}

\author{
Wenny Elsara \\ Universitas Negeri Padang \\ email: Wennyviky11@gmail.com
}

\begin{abstract}
The purpose of this study is to analyze the development of reading comprehension of junior high school students in Islamic texts through the SQ3R method integrated with digital interactive multimedia. This study was conceived as a collaborative classroom study conducted by Dr. Hamka2 Padang, Professor of SMP PMT. The subject of the survey was the 8th grade consisting of 24 students. The survey was conducted in a cycle of planning, action, observation, and reflection. The researcher and his colleagues the cycle consists of three sessions. The researcher and his colleagues used observation checklists, field notes, camera records and tests to collect data. As a result, it was found that the SQ3R method can improve the reading comprehension of students. There were 19 students $(75 \%)$ who scored more than 80 out of 24 students, and 6 students failed to achieve the score. The study was completed after the third session of Cycle 1, where the student proficiency test results met the success criteria. Based on this result, researchers have come to the conclusion that the implementation of SQ3R methods integrated with digital interactive multimedia in the teaching and learning process can improve students' ability to read Islamic texts.
\end{abstract}

Keywords: developing, reading skill, SQ3R method, digital interactive multimedia

\section{Introduction}

Reading is a linguistic, sociological, and psychological dimension (Stubbs, 1980). It is the interactive process between the text and the reader, and the reaction between the text and the reader's experience. Reading can make readers smarter because the more you read, the more you get. Help readers unleash their intelligence. Once you start reading, you will be immersed in a sea of knowledge, linking words, sentences, and paragraphs to each other and to the various topics you read.Reading skill is one of stage of reading comprehension.

According to the reading hierarchy of Crowley and Mountain (1995), reading comprehension follows a literal interpretive comprehension. Readers can understand the author's ideas in the text (McWhorter K.T., 1980). They usually focus on the author's ideas based on their own experience. They determine how they react emotionally and intellectually to the text. To learn to read, you need to understand that the ideas on the page are intended to teach, persuade, entertain, inspire, or advise the reader. It also helps in evidence-based decisions (Knott, 2019). Reading helps readers discover and understand the author's arguments and makes assumptions and opinions based on what they are reading. In summary, reading comprehension is an author-reader dialogue in which the reader reads the text carefully, responds to the author's ideas, and assesses the validity of the author's message. 
Teaching English, especially to younger students, is strongly encouraged so that students can communicate freely and accurately, both individually and in groups, through written and oral communication (Marzuki, 2017). In addition, text reading tends to become a major component of English as students become familiar with a variety of texts related to the subject of study (Gersten et al., 2001; Jitendra, 2011; Marzuki et al., 2018). This has forced English teachers to maximize their efforts to apply text reading pedagogy so that learners can capture the information conveyed in the text (Harmer, 2007; Wei et al., 2012; Gunning, 2013; Joseph et al., 2016).

Teachers must be aware of the needs of their students, including their motivation to read and the purpose of reading in everyday life. Reading for a variety of purposes is essential to academic and academic success in general, especially for middle school students. For them, reading skills can open up new worlds and possibilities. This will allow you to acquire new knowledge, enjoy literature and engage in daily activities indispensable to modern life: articles, magazines and brochures. who they read (Radcliffe, 2004; Williams, 2005; Harmer, 2007; MorganThomas, 2012; Li et al., 2014).

Second of all, the students have to read and answer the question related to the text as fast as possible. For this reason, the researcher considers that teacher should be able to motivate the students in order that they can capture messages conveyed bythe text. Finally, to solve the problems stated previously, the researcher is eager to implement SQ3R as an effective method to improve students' reading skills.

The SQ3R is a useful method for fully absorbing written information. SQ3R stands for "Survey, Question, Read, Recite and Review." It provides the students with a systematic approach for studying a text assignment. By using the SQ3R to actively read a text, the students can get the maximum benefit from their reading time. It also enables them to comprehend the reading texts as well as answer the reading questions precisely (Artis, 2008; Holes, 2008; Feldt et al., 2009; Baier, 2011; Carlston, 2011; Ari, 2014; Al-

Ghazo, 2015).

The main goal of reading education is to enable students to understand the text they are reading. Comprehension is a major part of reading. Basically, reading aims to convey meaning through understanding. When comprehension declines as they read, students must find ways to increase their comprehension. This is where the importance of knowing reading teaching methods and strategies comes into play to facilitate the reading process and to give students a clear idea of what they are reading. Students feel frustrated when they don't understand what they're reading and actually lose motivation. Teachers need to develop and teach different methods or strategies to help students fill gaps in understanding.

The ultimate challenge for teachers is to know exactly which approach, method or strategy is useful, actionable, enjoyable, and most beneficial for learning, as each student has different needs. Researchers share their thoughts on why they are interested in learning to read. First, the researcher was HAMKA professor Dr. Conducting preliminary observations at SMP PMT at HAMKA 2 Padang, learns what happened in the learning and teaching process. She also interviewed several English teachers. The real problems most students face with reading skills are identifying the main ideas of a paragraph, determining their general structure, and answering text questions. You may also not be able to perform exercises or assessments precisely at the time specified by your teacher. As a result, students need additional time to complete tasks. These issues were identified based on the researchers' prior observations of students' performance in both the teaching and learning process in the classroom and in exercise and assessment. Researchers have found that students face problems not only because they look up unfamiliar words and then take the time to open dictionaries or ask their friends what the words mean, but also because they don't understand what the text is about. This phenomenon showed that the majority of students had low reading ability and motivation.

To make reading a fun and engaging learning experience, you need media available online. Interactive digital media is any material or media that contains digital content in the form of text, images, and video in modules in an educational package, including units of educational material that can be read 
or learned on their own using an interactive display. Interactive Learning can be systematically combined with various educational aids such as video, audio, text and graphics to target interactive learning with students (Prastowo, 2012).

Several studies have been conducted regarding the development of teaching materials and media. In the study of Fitravati, Tiarina, and Vahyuni (2014), the study found that students needed textbooks presented in text and audio formats. This was followed by another study by Fitrawati and Siarif (2018) on the development of interactive e-books for advanced grammar courses. In 2013, Sugianto and Muladi (2013) conducted a study on the development of interactive learning tools based on digital media for science education at the high school level. The result is visual circular motions for multimedia notebooks and physical objects. Finally, further research is still needed to discuss the development of interactive digital learning materials for learners with reading abilities. Based on the description above, research should be conducted as described in the heading Developing SQ3Rs Using Interactive Digital Media for Students Learning Reading Skills. Professor Hamka 2 Padang on Islamic Texts from SMP PMT ".

\section{Method}

This study was conducted by SMP PMT professor Dr. Designed as a classroom study jointly conducted by HAMKA 2 Padang. The subjects of this study were 24 students in the 8th grade of elementary school. Researchers and co-authors jointly developed lesson plans, prepared textbooks and digital interactive media, and implemented action plans. The research carried out the stages of planning, action, observation, and reflection in a circular fashion (Stringer, 2008; Bogdan \& Biklen, 2010; Fraenkel et al., 2011; Kemmis, McTaggart \& Nixon, 2013; McNiff, 2013; McKernan, 2013). A cycle consists of three meetings. The researcher and his colleagues collected data using observation checklists, field notes, camera recordings, and tests. The success criteria for this study focus on your area of interest. Because researchers were conducting research on learning to read using the SQ3R, success criteria included classic performance on a reading test. In other words, this study was successful when $70 \%$ of students scored 80 or higher. It follows the minimum success criteria used in this class.

\section{Result and Discussion \\ The Result of the Observation on Lecturer's Performance}

The observation was done at the same time the researcher and the students conducted teaching and learning process in the classroom. The observation was done in order to know how far the researcher in this case as a lecturer of English performed the action that he has already constructed in lesson plans. There were 29 items would be observed by collaborator through the observation checklist. The collaborator putted a Tick $(\sqrt{ })$ on one of option columns for each item. The options were yes or no the items were conducted by the researcher. Since this research was planned for three meetings, the researcher wants to found the results in three parts; meeting 1, meeting 2 and meeting 3 . The results are as follows:

\section{Meeting 1}

Looking at the results of the observation checklist in Session 1, it can be seen that the investigator did not fill out all the items. She rewards students for completing assignments. For example: praise, praise, or appreciation. This is very important during class as students are motivated to participate in class. So, follow the lesson to the end and you will find the answer to your question. Another important point is that the researchers did not ask the students for opinions on their current activities. Finally, in her postal activity, she also did not paint verbally and took her materials to the next meeting. Based on the 
results, she asked the researcher to rate herself and she thought more about what she would like to say before the next meeting.

\section{Meeting 2}

At the 2nd meeting of, all questions were led by the researcher. She made good use of her time and was energetic enough to teach her classes. She asked the students questions in advance about the topic. He applied the SQ3R method carefully and systematically. She also more actively supervised and guided students during method implementation. What he did at this meeting was much better than the previous one. But she still has to work hard and prepare well for the next one, the last training meeting. This also meant that the third meeting was the last opportunity in Cycle 1 for teachers to apply the SQ3R integrated with digital interactive media.

\section{Meeting 3}

At the third meeting, the researcher has completed all the work. She implemented the SQ3R method step by step as already planned. This means that she met all the aspects suggested in this method. She also actively supervised and guided students during the implementation of the methods. This indicates that the researcher was well trained at the time.

\section{The Result of the Observation on Students' behavior}

The components of the table above relate to student education and learning behavior at Conference 13. The results show that in Session 1, no student asked about the instructor's instructions on this topic. They ignored the topic because there were no intriguing introductory questions. During the work, half of the students could not hear the teacher clearly and did not understand the teacher's instructions. Students often ask what to do after class. In the follow-up work, very few students actively answered the instructor's questions and looked back on the lesson. The same scale from conference 1 to conference 3 is in the implementation of the SQ3R method.

This is an English reading class, and it was difficult for students to concentrate on reading comprehension, so researchers used the SQ3R method carefully, a little slowly, and powerfully. He raised her voice to get the students' attention. Especially in Session 1, they were the first opportunity to present a method and he neglected to tackle some important points of the preparatory work. At the first meeting, the students weren't asked difficult questions, but they were still focused on reading. One At the first meeting, the students weren't asked difficult questions, but they were still focused on reading. One of the great things about SQ3R is that it can motivate you to read. It was the students who were easy.

They were comfortable with the components. The same thing happened to me at the second and third meetings of the learning process taught in the classroom. On the other hand, the observation results were not significantly different. In the last two running meetings, the instructor's performance was much better than the previous meetings. Therefore, it also influenced the reading behavior of students in the classroom. They could hear the instructor and understand the directions given to them. You can also answer or answer the instructor's questions in advance. You can then interact and actively participate in the implementation of the SQ3R method during the activity. Finally, the post-activity was able to answer the instructor's questions related to reflection on previous lessons and complete the assessment in a timely manner.

\section{The Result of the Observation on Lecturer's Document Preparation}

The learning items in the table above relate to the instructor's preparation of the syllabus, textbook, textbook, report card, and class report card. The data first shows that all items in collection 1 are available. The researcher prepared a lesson plan that included the implementation of the SQ3R method. In order to prepare a PowerPoint textbook and show it to the students, I needed an in-focus and a laptop. The 
instructor used a projector and a laptop to support the implementation of the method and displayed pictures to entertain the students. For follow-up activities, the researcher also prepared evaluation and exhibition sheets. Second, the data from Conference 2 matches the data from Conference 1 . This means that the researcher has prepared all of the observations above before entering the classroom. Third, the outcome of meeting 3 is almost identical to that of the other meetings. The researcher had already supplied himself with these five components as shown in the table above, but unfortunately the electricity was not working properly at the time. As a result, he could not use the learning environment optimally. All he needs to do is show the drawings on a piece of paper that students need to use the SQ3R.

\section{The Result of Achievement Test}

When conducting research in the form of classroom research, researchers, an important point to emphasize is that they conduct tests on students. The researcher and his collaborators worked together to prepare an achievement test following the implementation of the SQ3R method. Twenty-four students took part in the test. The time allotted for completing the test was 60 minutes. This was to determine if students could meet the success criteria for this study. This test was also used to measure how far students can go after learning reading skills with the SQ3R. The test results can be seen in the following table.

The researcher has to explain firstly how to compute the individual score of eachstudent before he computed the classical achievement. He used the formula, as follows:

$$
\text { Students Score }=\frac{\text { Achievement score }}{\text { Maximum Score }} \times 100
$$

For example, a student with the initials "AR" gets a score of 26 by adding multiple-choice scores, which is TRUE FALSE. That is, his correct answer on the test was 26 points, of which 18 multiple choice and 8 true false. Find the points earned ( 26 points), multiply that amount by 100 , and divide by the maximum score (30 points). The individual AR scores are as follows:

$$
\begin{aligned}
\text { Score } & =\frac{26}{30} \times 100 \\
& =86.6
\end{aligned}
$$

The calculation of AR's individual score was only as representative sample from other students' scores on the test. After noting the individual score of the students, then, the researcher computed the students' success in reading test classically by using the formula is as follows:

The total of students who get scores greater than or equal to 80 :

$$
\text { Classical Achievement }=\frac{\text { student score }}{\text { the total of students who join the test }} \times 100
$$

It can be seen on the result of achievement test that there were 6 students who got score less than 80 and 18 students who got score equals or greater than 80 . It means that the six students did not pass the lesson because their scores could not archieve the minimum criteria of success. So, computation of the classical achievement is in the following:

$$
\text { Classical Achievement }=\frac{18}{24} \times 100=75 \%
$$


The result above shows that the classical achievement $75 \%$ was greater than $70 \%$. It indicated that the result met the criteria of success. As stated previously in criteriaof success that if individual achievement score was equal or more than 80 and the total classical percentage was at least $70 \%$, it means that this study was successful.

Based on data collected from three meetings of cycle 1, the researchers presented the reflected results as follows: The instructor implemented the SQ3R method well in the three action meetings, and the instructor followed the steps suggested in the SQ3R method: ask questions, ask questions., read, declare and repeat. The instructor provided the SQ3R worksheets to help students manage their tasks well, and the instructor provided time limits for applying each step of the SQ3R method.

It aims to grab the students' attention and focus on the implementation of the method, after which the instructor explained the textbook well to the students, including the general structure of the narrative text and the main idea of the paragraph. The instructor then effectively controls the use of time so that the learning and teaching process can be carried out in time, then sets time limits to direct students' attention and focus on the given tasks and assessments, and finally implements the instructor method. Actively supervised students during SQ3R and task completion. And the following are the reflection results of the students. The students read the text intently.

Most students were able to understand the entire text without opening the dictionary to learn the meaning of complex words, but some (4) students still had to open the dictionary. And most of the students (18 students) were able to complete the assignments, assessments, and reading tests on time. This meant that while motivated to complete all tasks given, some students (6 students) who did not complete tasks on time were given an extra 10 minutes. Most students actively answer the instructor's questions. Students participated in reading classes with enthusiasm and joy, especially after the SQ3R method was introduced. For the first time, students wondered what this text was talking about, and they were delighted to be able to answer their questions after actively participating in the implementation of this method.

\section{Conclusion}

Researcher's SQ3R technique is effective in developing students' reading skills in Islamic texts. The primary criterion for evaluating a student's development is the assessment received during the exam. Analysis of achievement test data showed that 18 of the 24 students $(75 \%)$ in this study scored 80 or higher. This means that the student's performance on the reading test met the success criterion (70\%).

\section{Acknowledgments}

I dedicate this scientific reading skill and also my special respectful to beloved family; parents, husband, and my children. Thanks a bunch for all supports and affection.

\section{References}

Al-Ghazo, A. (2015). The effect of SQ3R and semantic mapping strategies on reading comprehension learning among jordanian university students. English and Education, 4(3), 92-106.

Ari, G. (2014). The effects of SQ3R and DR-TA reading strategies used by fifth grade students on comprehension.

Artis, A. B. (2008). Improving marketing students' reading comprehension with the SQ3R method. Journal of Marketing Education, 30(2), 130-137.

Baier, K. (2011). The effects of SQ3R on fifth grade students' comprehension levels (Doctoral dissertation, Bowling Green State University). 
Bogdan, R. C., \& Biklen, S. K. (2010). Foundations of qualitative research in education. Qualitative educational research: Readings in reflexive methodology and transformative practice, 21-44.

Carlston, D. L. (2011). Benefits of student-generated note packets: A preliminary investigation of SQ3R implementation. Teaching of Psychology, 38(3), 142-146.

Feldt, R. C., \& Hensley, R. (2009). Recommendations for use of SQ3R in introductory psychology textbooks. Education, 129(4). 